\title{
The 2007-08 Financial Crisis from a Marxist View
}

\author{
Fernando Henrique Taques ${ }^{1,2}$, Henrique Pavan Beiro De Souza ${ }^{2,3 * \#, ~ D o u g l a s ~ A l c a n t a r a ~ A l e n c a r ~}{ }^{4}$ \\ ${ }^{1}$ Mackenzie Presbyterian University, São Paulo, Brazil \\ ${ }^{2}$ Metropolitan United Faculties (FMU), São Paulo, Brazil \\ ${ }^{3}$ Federal University of ABC, Santo André, Brazil \\ ${ }^{4}$ Federal University of Pará (UFPA), Belém, Brazil \\ Email: *hpbsouza@gmail.com
}

How to cite this paper: Taques, F.H., De Souza, H.P.B. and Alencar, D.A. (2017) The 2007-08 Financial Crisis from a Marxist View. Modern Economy, 8, 1069-1081. https://doi.org/10.4236/me.2017.89074

Received: June 16, 2017

Accepted: August 26, 2017

Published: August 29, 2017

Copyright $\odot 2017$ by authors and Scientific Research Publishing Inc. This work is licensed under the Creative Commons Attribution International License (CC BY 4.0).

http://creativecommons.org/licenses/by/4.0/

\begin{abstract}
The international financial crisis in the American economy in 2008 brought again to the fore an economic discussion on the origin of crises. Previously, only the 1929 accident had such magnitude, putting in discussion the economic policies adopted until then, raising the economic debate between several economic schools of thought. The effects of the crisis were notorious about the financial markets, but also hit hard the real economy, especially the productive sector, such as industry and services. Indeed, the consequences on employment, income and on the level of trade were not only felt by the American economy, but also in other countries. Starting from this context, this article aims to describe the propelling elements and the forms of theoretical manifestation of the crises under a marxist perspective, seeking to understand the origins of this phenomenon from the marxist stream, as well as discourse about the 2008 crisis and its developments on the American economy. Therefore, it makes use of economic indicators on the evolution of prices and sale of real estate in the United States, growth rate of gross domestic product and employment and income between 2000 and 2010. The methodology also includes the arguments on the capital bearer of interest and fictitious capital in addition to the role of the rate of profit, exposed in the Marxist conception of the origin of financial crises. As a result, it can be seen that the fictitious capital dominates economic and political relations so that the crisis has its origin on capital and not in the productive sphere.
\end{abstract}

\section{Keywords}

Crisis, Marxist Theory, Subprime

${ }^{\#}$ With a period of internship at the International Institute of Social Studies-Erasmus University of Rotterdam. 


\section{Introduction}

Financial crises have been recurrent and have shown diverse effects on countries with different levels of development. From an economic point of view, this fragility can affect public and private investment expectations, consequently reaching income, employment, price and consumption levels. Hence, the chain effect directly affects society, not just the financial side of the economy. With the financial crisis of 2008/2009, the issue gains more space in academic debate, especially because of the origin of the crisis in the world's largest economy and the developments over other nations. Several researchers have sought to better understand this phenomenon from the perspective of schools of economic thought. The issue is now being studied on two fronts: understanding the factors that determine the origins of financial crises and what the consequences are for countries suffering from this adversity.

It is argued that the cyclical behavior of the capitalist accumulation process takes place by the capitalist mode of production. The interest bearing capital is given when the owner of the capital grants a loan to a particular capitalist in order to obtain a financial return on the loaned capital. In this case, there is no stage in the production of the real economy in the capital cycle. This fictitious capital, which does not add real value, can actually have adverse effects on the real economy [1] [2].

The American crisis of 2008 has elements of a financialization process that begun in the decade of 1970. Expanding the real estate financing by using home mortgages as collaterals, the financial institutions refinanced debts, thus, this process generated a speculative movement within a system that generated liquidity among financial companies.

This research purpose is to understand whether the 2007-08 financial crises can be explained by the Marx theory. To reach such research purpose, the methodological strategy is based on bibliographical review of the Marxist perspective on financial crises and data on the American economy in the period in question, namely: growth rate of gross domestic product, real interest rate, level of consumption and value added from the industry, in the period between 2001 and 2010. The adoption of indicators of the industry seeks to confer effects on the real economy at a period marked by a sharp guided growth in the real estate financing model.

The hypothesis of the research is to verify whether the crisis of 2008 presents elements that its origins can be explained by the theory of the capital bearer of interests approached by Marx. Throughout the decades of the XX and XXI centuries, several economies went through financial instabilities, to a lesser or greater magnitude. In this scenario, the main contribution of the research is aimed at a better understanding of factors determining the instabilities of the financial system. In this way, policymakers can take preventive action to avoid or mitigate effects on the real economy as well as on the financial and credit markets.

Besides this introduction and conclusion, this research is divided into three 
more sections. The first presents the theory of interest bearing capital and fictitious capital. The second chapter explores the concept of the declining tendency of the rate of profits. Together, these theories stand as important landmarks for the understanding of the origin of financial crises in the works of Marx. Finally, the third comprises the analysis and description of the crisis of the financial crisis of 2008/2009 and its respective origin from the Marxist perspective.

\section{Interest-Bearing Capital in Marx Theory}

Money accumulation by itself is not capital, in the sense that it becomes capital from the moment it can be lent to commodity capital or even commercial capital. Thus, it begins to assume another use value, the profit production. Of course, the way to increase capital is through production of products. In Marx words:

On the basis of capitalist production, money-taken here as the independent expression of a sum of value, whether this actually exists in money or in commodities - can be transformed into capital, and through this transformation it is turned from a given, fixed value into a self-valorizing value capable of increasing itself [1] [2].

There is a part of profit that a capitalist pay to other capitalist in order to invest on production, which is called interest.

Lets suppose that there are two capitalists, A and B. Fur there more suppose that A advances capital in money form to B. Since B has the money, this is transformed into capital, in the movement $M-C-M$ and then it returns to capitalist $\mathrm{A}$ as $M$, indeed it retorns as $M+\Delta M$, where $\Delta \mathrm{M}$ is the interest. Then, the movement can be expressed as $M-M-C-M-M$. The double expenditure of the money as capital, as Marx explains, is a transfer from A to B. Therefore, the double $M$ is part of the profit that $\mathrm{B}$ transfers to the capitalist $\mathrm{A}$ in form of interest. The interest-bearing capital is the movement in which the owner of money desires to valorize this as interest-bearing capital parts with it to someone else. Therefore, makes the money into a commodity as capital. This capital is made not only for capitalist B, but also to capitalist A. In Marx words:

The capital lent out flows back in a double sense. In the reproduction process it returns to the functioning capitalist, and then its return is repeated once again as a transfer to the lender, the money capitalist, as repayment to its real proprietor, a return to its legal starting-point [1] [2].

Money becomes capital, for there is a connection to the total movement of capital. In this way, from the money is that begins the capitalist process of production. Marx expressed the real movement of interest bearing capital through the following scheme:

$$
\begin{gathered}
\stackrel{ }{\longrightarrow} M P \\
-L F
\end{gathered}
$$

where, $M$ is money, $M P$ means of production, $L F$ labour force, $P$ productive capital, $C^{\prime}$ commodity for sale, and $M^{\prime}$ the money already added to the 
surplus-value. The expression represents that the starting and ending point of capital, constituting the monetary capital, $\left(M-M^{\prime}\right)$. Furthermore, its obligatory point of valorization is the passage through the form of productive capital. It is also worth mentioning that the formula is even more relevant if the borrower is a commercial capitalist.

Thus, when the owner of money capital grants the loan of his capital to an industrial capitalist or even to a wholesaler, he is not carrying out any part of the cycle that capital passes in capital production, since the return of the borrowed money completes the act performed. That is, the assignment of the money for a certain period of time.

At this moment, money starts to assume another use value, derived from the profit it produces, once it has been transformed into capital. It is in the quality of potential capital, of means of producing profit, that it becomes a commodity of particular genre. The possession of money capital grants its owner, at the time of the loan, the right to the profit part of the industrial or commercial capital being in the form of interest, therefore, the interest constitutes deduction of the profit, originating from the surplus value.

From this point of view, the possession of money confers the right to demand interest, regardless of the result of the application by industrial or commercial capital. For Marx [2] this is the most reified, more fetishistic capital as to the owner of the money its simple possession is due to interest, there is no perception that this arises from the deduction of profit.

According to Chociay and Neves [3], average market prices tend to equate to the monetary expression of the value of commodities. However, fluctuations between supply and demand cause prices to fluctuate around this level. For the interest rate the determination takes place through the competition (monetary capital), since there is no value.

For Marx, interest is not an inherent condition of capitalist production, since the realization of the loan between the creditor capitalist and the capitalist does not constitute an act of the actual process of capital circulation [2].

In this way, the commodity fetish is constituted from the gain of the industrial capitalist as remuneration of its activity, as well as the interest that is taken as the natural property of the monetary capital when it is valued for its respective owner.

\section{Downward Trend of the Profit Rate, Credit System and Financial Crises}

In the Marxist framework, it is important to stress the central role played by the financial system as a kind of coordinator of capitalist activity. Its role in the determination of financial flows, channeling whether production or rentism configures, above all, a network of power that unifies the producing units. From this organization via the market, the ability to influence and capture political interests becomes a means of maintaining, increasing and perpetuating power that explains policies of financial deregulation that have provoked the subprime crisis. 
Harvey [4], thus summarizes the central role of financial capital in the capitalist system.

Harvey [4] argues that insofar as individual capitalists, acting in self-interest and seeking to maximize their profits in a competitive environment, adopt technologies and make decisions that are inconsistent with balanced accumulation, the credit system offers the possibility of controlling this misconduct. The contradiction between individual behavior and social class requirement exerts a powerful destabilizing influence on the path of accumulation. Stability can be imposed on an otherwise anarchistic and uncoordinated capitalism by appropriate organization and management of the credit system.

If the credit flow balances the system, functioning as a link between production and consumption and as a mediator of class conflict and potential individual conflicts within the capitalist class itself, how do crises still occur?

The explanation for these phenomena lies in some factors. The equalization of profit rates provided by the credit system increases the intersectoral and cross-company competition for technological innovation, reinforcing the tendency to overact cumulation. In other words, the expansion of the organic composition of capital resulting from the accumulation process would tend to push production prices upwards. However, the credit system enables the continuation of this process which causes even greater gap between the accumulation of physical capital and labor utilization. That is, credit intensifies the mismatch between supply and demand [5].

At the same time, the emergence of a class fraction that holds interest-bearing capital generates contradiction in the system itself. As argued before, they are responsible for the dynamics of the general accumulation and coordination-via credit distribution and equalization of profit rates-of the capitalist system. However, managers of financial capital and their own holders act from their individual interests, exploiting the advantages of this position to act in the financial markets seeking profitability from their own speculation. This would be the realm of fictitious capital, in which its value is not based in actual production, depending only on movement dynamics in the same market. Therefore an increasing autonomy of the financial sphere is proceeded, something immanent to the category of "money" exposed in the previous section. However, it is clear that this autonomy is apparent in that the generation of real value still lies in the production cycle, being the very possibility of crises arising from the potential mismatch between production and sales. In other words, the sphere of production is still decisive even when financial capital appears to demonstrate its sovereignty [6].

Alves Pinto [7] highlights the emergence of the legal entity as an indicator that the relationship between fictitious and productive capital remains, in essence, with its outlined fields, but not totally separate. Thus, the shareholder can not at the same time owner of machinery and equipment. These belong to the legal entity, and the shareholder is entitled to part of the profits and dividends. But it ultimately depends on production, profit-making, and surplus-value. It is also 
true, however, that the development of financial markets via the sphere of circulation makes private wealth represented by bonds, stocks, debentures etc., directly influenced by the oscillations of supply and demand typical of this market. With the financialization, the plasticity of this movement gains body in time and space, giving it an apparent autonomy. Furthermore, the cycle gets barred at the very limit of income generation and this means returning to the realm of production and real investments in equipment, workers and goods.

Harvey [4], explaining Marx's conclusions, states that the credit system allows "an enormous expansion of the scale of production and/or enterprise," replacing the individual capitalist with the "social" and "associated" forms of capital (joint-stock companies, corporations, etc.). This leads to the separation of management ownership, the creation of monopolies which cause state's interference and the rise of a "new financial aristocracy." And with it "the material development of the productive forces is accelerated" and the world market is established. But it also accelerates the formation of crises and brings to light the "elements of disintegration" of capitalism. Marx calls this "abolition of the capitalist mode of production within the capitalist mode of production itself, and therefore a self-dissolving contradiction." The framework outlined by Harvey [4], therefore, gives an interesting illustration of the dynamics of financial crises in Marxist theory: there is a clear contradiction between the development of productive capital and financial capital, so that this process results in a profound change in a system that ends up denying itself.

Moreover, applying the previously worked concepts in historical terms, it would be important to approach the subprime crisis as a manifestation of a structural crisis of capitalism, associated with the so-called third industrial revolution. It is already known that the imperative of capital to continue denying living labor in its pursuit of technological innovation and increased productivity results in the declining trend of profit rates. Herein lies the central contradiction of the system: the search for productivity reduces the unit labor costs transferred to the commodity, which in itself represents a decrease in surplus value and profits. In reaction, the capitalists act to further reduce its costs depressing wages, generating deflationary trends and crises of overproduction. Therefore, what has been seen since the last decades of the twentieth century is a phase of productive adjustment at the heart of capitalism, inducing the greater use of frontier technologies with the concomitant reduction of the employment level. The increase in credit and financial deregulation can be seen as results of this process of work precarization and productive restructuring: political leaders provide some relief for the middle and working classes facilitating the massive granting of mortgage loans, as well as the recovery of profitability of capital is driven by the financial sector as a result of the explosion of the derivatives market, which allows for securitization and risk transfer, in a move where speculation with securitized securities represents part of the gains of financial institutions.

Gontijo [8] argues that there comes a time, however, when any such event-such as the suspension of payments by BNP Paribas from its hedge funds 
on 9 August 2007 or the bankruptcy of Lehman Brothers in the September 15, 2008-makes clear to the experts the fragile house of cards on which the speculative process is based, giving rise to the panic that signals the unfolding of the financial crisis, through which begins the process of adjustment of the economy, including suppression of the gap between production and consumption, of intersectoral imbalances and of the detachment of the financial sphere from its "foundations".

Although it has been argued in this work that it is possible to interpretate the 2007-08 financial crises from the Marxist point of view, Sardoni [9] argues that this interpretation would be misleading, since the Marxist theory cannot explain the reason the crises impact the medium run. Sardoni [9] argues that the Marxist theory cannot explain the long period of stagnation following the eruption of the mentioned financial crises. This author argues that in the Marx theory, a crisis is following by a period of economic growth, since the hypothesis made by Marx includes free-competitive economies. However, the modern economies are mainly monopolistic. This would be the main reason in which Marx's theory could explain the 2007-08 financial crises. However, Basu [10] argues that Sardoni [9] interprets Marx's theory as an under consumption theory, which would explain the reason why Sardoni [9] argues that the economy should recover after a short span of time. Sardoni [11] argues that his theory does not rely on under consumption interpretation, but his argument is not convincing.

\section{The Financial Crises 2007-09}

In this section we undertake an analysis of the main features of the subprime crisis in the light of Marx's idea that financial crises arise from the deep characteristics of capitalism, where interest-bearing capital and, in particular, fictitious capital have assumed dominance in economic and political relations.

After the crisis of the 1970s and 1980s, in the United States, a model of financing-based on short-term bank liabilities which financed mortgages, having the real estate property as warrant-was developed. In this scenario private financial institutions were not active in the real estate financing market. As a stimulus, a speculative movement was created where mortgages could be transformed into liquidity securities and could be traded in the global financial system. This emission of bonds, on the other hand, was not conditional on the sale of securities, but rather could bind other securities. This dynamic of securitization has generated a massive supply of securities derived from mortgage credit. Such innovation brought to the agents a sense of risk reduction to the extent that such assets had as characteristics their huge liquidity and demand in the deregulated global markets. Bonds such as Credit Default Swaps-issued by AIG-and Mortgage Backed Securities-issued by real estate financing institutions-were widely traded, especially at a time when the market was boosted by modest interest rates [11] [12].

According to Mollo [13], this predominance of financial operations to the detriment of the productive ones results in the loss of relation between the real 
production and the circulation of values, according to the theoretical approach of the fictitious capital. In this sense, assets of a financial nature, with unevaluated or unbalanced real production, or the growth of interest participation in a way favorable to the accumulation of financial capital, are situations where it is possible to observe the predominance of fictitious capital.

However, the financial sphere detaching movement has its roots in the real economy, especially when it comes to real estate, which presents imminent instability and depends on the credit for its existence. According to Gontijo [11], the subprime crisis represents the culmination of a process of the construction cycle reversal which started from the mid-1990s. The importance of these cycles results in the fact that their effects favor the increase of investments In general, given its multiplier effects, the construction industry itself has the power to drag a large number of jobs into correlated industries, as well as to activate the consumer goods industries and public investments in urban infrastructure. However, this same sector carries with it a highly pro-cyclical instability, presenting a positive correlation with the growth of income and aggregate demand, as well as the supply of credit. But the origins of this cycle can be traced back a few decades.

According to Carcanholo [14], this same process of financial and banking deregulation, initiated in the 1980 s, directly reflected a greater freedom to issue liabilities and allocate these resources to other assets, which implies an absence economic regulation itself. Subprime contracts were considered to offer high risk of default by the borrower, so the lender (mortgage agencies or banks) merged subprime contracts with less risky ones and resold the bond to other financial institutions or even directly in the market. The set of securities were classified as "low risk" and their pay was higher, counting on insurers. In this way, long-term debt was financed with short-term speculative resources in the financial market itself, with different time frames for receipt and payment [11] [12].

The consequence was an increase in the financialization of the economy, but with no relation to the incomes generated in the productive process. Then, the result was a growth process based on fictitious capital, with no return in the productive process which is the means of guaranteeing sustainable growth of production and income [13].

The crisis of 2008/2009, therefore, represented the outbreak of this model adopted until then. The stimulus for real estate acquisition was even given to clients who did not have a proven regular income, a stable job or even a bank account that qualified them as possible payers. As Carcanholo [14] points out, real estate prices have indicated a significant increase, since the supply of financing expanded widely, reflecting good conditions for borrowers. In an international liquidity environment with a concomitant absence of regulation, credit expanded more than proportionately than the productive sector, generating a typical instability of the behavior of the fictitious capital.

The results of the crisis effect can be directly observed through the indicators of the US economy (Table 1). 
Table 1. US macroeconomics indicators (2001-2010).

\begin{tabular}{ccccc}
\hline & $\begin{array}{c}\text { Variation of } \\
\text { GDP }(\%)\end{array}$ & $\begin{array}{c}\text { Real Interest } \\
\text { rate }(\%)\end{array}$ & $\begin{array}{c}\text { Final Consumption } \\
\text { (billions US } \$)\end{array}$ & $\begin{array}{c}\text { Industry-Added } \\
\text { Value (\% of GDP) }\end{array}$ \\
\hline 2001 & 0.97 & 4.54 & $8,648.2$ & 22.16 \\
2002 & 1.78 & 3.09 & $9,035.4$ & 21.27 \\
2003 & 2.80 & 2.08 & $9,521.0$ & 21.40 \\
2004 & 3.78 & 1.54 & $10,129.0$ & 21.68 \\
2005 & 3.34 & 2.87 & $10,774.1$ & 21.95 \\
2006 & 2.66 & 4.73 & $11,393.8$ & 22.37 \\
2007 & 1.77 & 5.24 & $11,960.3$ & 22.18 \\
2008 & -0.25 & 3.09 & $12,382.1$ & 21.63 \\
2009 & -2.80 & 2.44 & $12,289.1$ & 20.15 \\
2010 & 2.52 & 1.99 & $12,724.4$ & 20.39 \\
2011 & 1.60 & 1.16 & $13,220.2$ & 20.63 \\
2012 & 2.22 & 1.38 & $13,594.8$ & 20.54 \\
2013 & 1.68 & 1.61 & $13,884.9$ & 20.72 \\
2014 & 2.37 & 1.43 & $14,420.9$ & 20.87 \\
2015 & 2.60 & 2.16 & $14,888.6$ & 20.03 \\
2016 & 1.62 & 2.17 & - & - \\
\hline
\end{tabular}

Source: WDI-World Bank.

The variation in US GDP already signaled declining growth rates since 2004, but at the epicenter of the crisis, between 2008 and 2009, the effects were felt most with negative swings in the product. While in the first moment it is possible to observe an increase in the supply of capital of a monetary nature and formation of expectations favorable to a scenario of price growth, the second period is marked by a cyclical movement that persisted. However, from the moment the demand of fictitious capital shifts the ability to discharge liabilities, then there is more support for higher prices and there is a break in the process [14].

This context is possible to be observed, since initially there is a growth of the economy sustained through consumption and credit, but a mismatch in 2004 with the increase of noncompliance and interest rates, which culminates in the reduction of real estate prices and fall in the supply of credit, which in turn leads to further noncompliance. It is also possible to observe a discrepancy between the real production and the financial circulation, which reflected heavily in the difficulty of financing the banks (or refinancing, in this case) and in the downgrading of corporate risk classifications, thus generating the need for state and central banks intervention. It can also be seen bank and other companies failures, including some listed on stock markets that lost large market value, which led some of them to change financial results in balance sheets to reduce the real impact of the crisis in question, a situation aggravated by the bankruptcy of Lehman 
Brothers at the end of 2008 [12] [13] [14] [15].

Almeida [16] points out that there has been a process of contamination from the financial sphere to the real economy in the period, a condition that demonstrates that production and circulation processes are not independent, but are closely related in the reproduction of fictitious capital. The spread of the effects on the real economy occurred via retraction for construction loans, which in turn reduces the level of economic activity that indicated signs of weakening in 2006. As a consequence, in the face of a process of real estate speculation, there was a fall in property prices, since the real growth of real estate prices in previous periods was not generated due to real but speculative factors. Therefore, the imbalance of the fall in the demand of real estate with supply restriction implied a fall in real estate prices.

Yet the combination of factors such as slow growth, continuing low interest rates, which have highly negative correlation with real estate assets, and the mortgage securitization process sparked a real boom in the property market. According to Gontijo [11], the expansion began in the mid-1990s, when real estate prices started to rise at a moderate pace (2.3\% a year during the 1995-2000 period). New impetus was given by the Federal Reserve's interest rate cut in the wake of the stock market bubble burst, particularly in the high-tech segment ("Dot.com") in 2000, followed by a further cut in interest rates after the terrorist attack of September 11, 2001. As a result, the federal funds rate reached only $1 \%$ in 2003, causing the costs of mortgage credit to reach their lowest level in forty years. This reduction in interest rates, combined with the development of the securitization process and the financial innovations introduced in the period turned the boom in the residential market frenzy, so that the average rate of increase in property prices was $6.4 \%$ per year in the period 2000-2005, with the peak being reached in 2005, a year in which household prices rose by around $14 \%$ [11].

With the increase of the basic interest rate in the United States many borrowers could no longer meet their mortgage commitments, generating therefore a widespread wave of defaults in the following months and, in turn, break in several companies of the economy [12]. According to Dantas [17], the growth in indebtedness levels of companies, families and consumers, were accompanied by mass layoffs due to the sharp fall in the level of production and demand for the products. As a consequence, there was an increase in the unemployment rate and in the State's intervention in order to minimize the effects of the crisis through fiscal expansion.

It is also possible to observe that the added value of industry as a proportion of gross domestic product declines initially in 2002 and then again in 2008 and 2009. In the first part of the decade, with the growth of the economy in the financialization of the economy, the expansion of credit is more than proportional to the expansion of industry, which in Marxist perspective would lead to a rupture of the system in the face of the expansion of the economy based on capital fictitious. From the outbreak of the crisis in 2008, national product's negative 
growth is accompanied by a drop in the pace of industrial production, a result which aggravates the effects on the real economy.

Even if we consider that, since 2010, there has been a recovery in indicators such as GDP growth and final consumption, one can notice that the structural pattern of financialization alongside with decrease in industry added value, remains. The available data about derivatives shows us that by the end of 2013, 14,261.6 billions were negotiated in North America. As of March 2017 (latest available figures by the time of this research), the traded amount rose up to 23.081 billions, and increase of $62 \%$ (Bank of International Settlements).

This phenomenon has been accompanied by an important recovery of credit oriented to private sector. On its peak, in 2007, the credit ratio reached $206 \%$ of the national product followed by a persistent decline until the bottom of $177 \%$ in 2011. As of 2016, it rose to $193 \%$, confirming a consistent upward trend. The same pattern can be seen as regarding the money supply, considering the concept of broad money. In 2009, it represented 91\% of the GDP and right after, in 2010 , there was a decline to $85 \%$. Since then there has been a continuous growth and the last figures, of 2016, show us a percentage very similar to that of 2009: 90.5\% (WORLD BANK).

This unfolding was made possible as far as money has come to represent the value, even if its price form departs and gets autonomized, so that the pursuit of making money without going through the production imposes itself and, if it is not controlled, it takes the form of hypertrophied fictitious capital. Thus, crises are generated by capital, whose first manifestation occurs in the financial sphere, passing then to other spheres, as occurred in the crisis of 2008/2009.

\section{Conclusions}

Interest, originating from a share of profit, is the main actor in the productive cycle of reproduction of capital in Marxist theory. The crisis in the financial sphere originates from theories of interest bearing capital, fictitious capital, and the declining trend of profit rates.

With respect to interest bearing capital, the constitution of the fetish takes place from the industrial capitalist's gain as compensation for its activity. In payment of interest, the industrial capitalist transfers to the monetary capitalist an additional sum of money as consideration for the use value of capital. In net terms, a value of use without value in itself has been changed for money, which has a determined value.

Another point is the fact that, when borrowed, bank money duplicates, since there are money and securities that represent rights over money. Therefore, a single monetary value has turned into two values, apparently, which is not possible, because only money constitutes real value.

The fictitious capital gains apparent power of coordination of the system by propitiating the continuation of the productive cycle and making the connection between supply and demand. However, their development provides bad price signals for capitalists who, inflated by the appearance of profitability, continue to 
invest in the production and accumulation of physical capital. Therefore, the tendency to over accumulate occurs. At the same time, the operators of financial capital begin to act as agents focused on their own interests, always seeking favorable transactions. At this point, the valuation of stocks and financial assets, as well as the inflation of productive company assets, are part of this financialization process. In other words, fictitious capital develops in seemingly autonomous terms facilitating the emergence of speculative bubbles and sophisticated derivative products. The subprime crisis was nothing more than a reencounter between the realm of fictitious capital and the realm of real production.

As for the costly technical progress of capital, on the basis of Marx's assumption, this generates an increase in the rate of wages and, consequently, a reduction in the rate of surplus value. However, the rate of profits would necessarily reduce even if the organic composition of capital remained constant as a result of the increase in the wage rate.

In this sense, the financial crisis of 2008/2009 reveals not only the expansion of forms of interest bearing capital, but in essence, mainly, the fictitious capital of dominating economic and political relations. Therefore, this crisis is a crisis of capital in which the financial sector fuels growth, smoothing the declining trend of profits, but ultimately generating bubbles and financial instability.

The main limitation of this research is the difficulty in measuring the rate of profit of the economy, as well as the relation between prices and the determination of the value that directly affects the understanding of the labor force and its monetary transformation, as Bortkievicz [18] and Seton [19] and reinforce Borges Neto [20] and Rotta [21] [22]. Indeed, in the absence of indicators there is more difficulty in observing the presence of financial vulnerability in Marx's perspective.

Another limitation is that it does not cover other theoretical perspectives on financial crises. Addressing the arguments of other schools of thought could point to further clarification on the subject, reinforcing understanding in the Marxist context or even raising criticism.

\section{References}

[1] Marx, K. (1985) O Capital. v.1, t. 1. 2nd Edition, Nova Cultural, São Paulo.

[2] Marx, K. (1986) O Capital. v.3, t. 1. 2nd Edition, Nova Cultural, São Paulo.

[3] Chociay, H. and Neves, L.S. (2007) O conceito de juros em Marx e Keynes e sua influência sobre os modelos de crises financeiras. In: Anais do XII Encontro Nacional de Economia Política, Sociedade Brasileira de Economia Política, São Paulo-SP.

[4] Harvey, D. (2013) Os limites do capital. Boitempo, São Paulo.

[5] Gontijo, C. (2009) A Teoria das Crises Financeiras: Uma Apreciação Crítica. Anais do XXXVII Encontro Nacional da ANPEC, Foz do Iguaçu-PR.

[6] Mollo, M.L.R. (2011) Crédito, capital fictício, fragilidade financeira e crises: Discussões teóricas, origens e formas de enfrentamento da crise atual. Economia e Sociedade, Campinas, 20, 449-474.

https://doi.org/10.1590/S0104-06182011000300001 
[7] Alves Pinto, N.P. (1997) O capitalismo financeiro. Crítica Marxista, No. 5, 9-26.

[8] Sardoni, C. (2015) Is a Marxist Explanation of the Current Crisis Possible? Review of Keynesian Economics, 3, 143-157. https://doi.org/10.4337/roke.2015.02.01

[9] Basu, D. (2016) Underconsumption, Capitalist Investment and Crisis: A Reply to Sardoni. Review of Keynesian Economics, 4, 208-218. https://doi.org/10.4337/roke.2016.02.06

[10] Sardoni, C. (2016) Marxian Theories of Crises: A Rejoinder. Review of Keynesian Economics, 4, 219-223. https://doi.org/10.4337/roke.2016.02.07

[11] Gontijo, C. (2008) Raízes da crise financeira dos derivativos subprime. Texto para discussão n. 342, UFMG/Cedeplar.

[12] Strachman, E. and Fucidji, J.R. (2012) The Current Financial and Economic Crisis: Empirical and Methodological Issues. Journal of Advanced Studies in Finance, 3, 95-123. https://doi.org/10.2478/v10259-012-0007-x

[13] Mollo, M.L.R. (2011) Capital fictício, autonomia produção-circulação e crises: Precedentes teóricos para o entendimento da crise atual. Revista Economia, 12, 475-496.

[14] Carcanholo, M.D. (2011) Conteúdo e forma da crise atual do capitalismo: Lógica, contradições e possibilidades. Texto para discussão s/n. Núcleo interdisciplinar de estudos e pesquisas sobre Marx e o marxismo, Universidade Federal Fluminense.

[15] Fahri, M. and Cintra, M.A. (2009) A arquitetura do sistema financeiro internacional contemporâneo. Revista de Economia Política, 29, 274-294. https://doi.org/10.1590/S0101-31572009000300017

[16] Almeida, A.C.S. (2009) As formas teóricas de manifestação da crise em Marx e a crise atual. In: XIV Encontro Nacional de Economia Política, São Paulo.

[17] Dantas, R. (2009) A grande crise do capital. Cadernos de ética e filosofia política, 14, 47-72.

[18] Bortkiewicz, L.V. (1974) Contribuición a uma retificación de los fundamentos de la construción teórica de Marx em el volumen III de el capital. In: Sweezy, P., Ed., Publicado inicialmente em língua alemã em 1907, 191-213.

[19] Seton, F. (1957) The Transformation Problem. The Review of Economic Studies, 24, 149-160. https://doi.org/10.2307/2296064

[20] Borges Neto, J.M. (2002) Duplo caráter do trabalho, valor e economia capitalista. Tese de Doutorado, Programa de Pós-Graduação em Economia, Universidade de São Paulo. https://doi.org/10.11606/T.12.2002.tde-22112002-133033

[21] Rotta, T.N. (2008) Dinheiro inconversível, derivativos financeiro e capital fictício: A moderna lógica das formas. Tese de Doutorado, Programa de Pós-Graduação em Economia, Universidade de São Paulo.

[22] Rotta, T.N. and Paulani, L.M. (2009) Teoria monetária de Marx Atualidade e limites frente ao capitalismo contemporâneo. In: XIV Encontro Nacional de Economia Política, São Paulo. 
Submit or recommend next manuscript to SCIRP and we will provide best service for you:

Accepting pre-submission inquiries through Email, Facebook, LinkedIn, Twitter, etc. A wide selection of journals (inclusive of 9 subjects, more than 200 journals)

Providing 24-hour high-quality service

User-friendly online submission system

Fair and swift peer-review system

Efficient typesetting and proofreading procedure

Display of the result of downloads and visits, as well as the number of cited articles Maximum dissemination of your research work

Submit your manuscript at: http://papersubmission.scirp.org/

Or contact me@scirp.org 